\title{
Minimal important change or difference for the oxford hip and knee scores following joint replacement surgery
}

\author{
Kristina Harris ${ }^{*}$, Andrew Price, Jill Dawson, Helen Doll, David Murray, Andrew Carr, David Beard \\ From 2nd Clinical Trials Methodology Conference: Methodology Matters \\ Edinburgh, UK. 18-19 November 2013
}

\section{Objectives}

i) to present a range of estimates of meaningful or minimal important changes/differences for the Oxford Hip Score (OHS) and the Oxford Knee Score (OKS) based on different approaches, and (ii) to identify the estimates that are most consistent and useful for application in specific contexts.

\section{Study design and setting}

Secondary data analysis of the NHS PROMS dataset which included 137,109 patients listed for hip replacement surgery and 156,788 patients listed for knee replacement surgery.

\section{Results}

Anchor based Minimal Important Difference (MID) was $\sim 5$ points for the OKS and the OHS and Minimal Important Change (MIC) was $\sim 9$ points for the OKS and $\sim 11$ points for the OHS. Distribution based methods showed that the Minimal Detectable Change $\left(\mathrm{MDC}_{90}\right)$ for the OKS and OHS respectively were 4 and 5 points.

\section{Conclusion}

This study produced a range of context-specific estimates of minimal important change/difference for the OKS/OHS. We would recommend, based on current evidence, that the OKS/OHS MIDs are used to indicate meaningful difference between patients (e.g. in clinical trials) and the OKS/OHS MICs to indicate meaningful change from baseline in a single group design. The $\mathrm{MDC}_{90}$ should be used to indicate change beyond measurement error on individual patients.
Published: 29 November 2013

doi:10.1186/1745-6215-14-S1-051

Cite this article as: Harris et al:: Minimal important change or difference for the oxford hip and knee scores following joint replacement surgery. Trials 2013 14(Suppl 1):O51.
Submit your next manuscript to BioMed Central and take full advantage of:

- Convenient online submission

- Thorough peer review

- No space constraints or color figure charges

- Immediate publication on acceptance

- Inclusion in PubMed, CAS, Scopus and Google Scholar

- Research which is freely available for redistribution

University of Oxfor

(c) 2013 Harris et al; licensee BioMed Central Ltd. This is an Open Access article distributed under the terms of the Creative Commons 